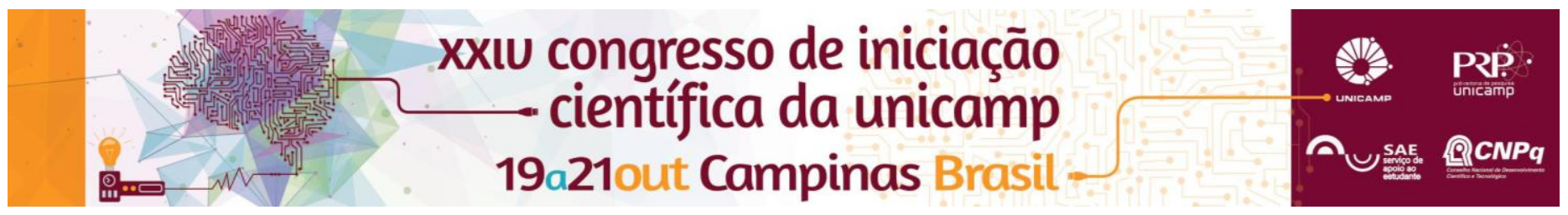

\title{
Papel do Fator Neurotrófico derivado do cérebro (BDNF) do Núcleo Accumbens no Componente Afetivo da Dor em Ratos.
}

\section{Ana Lígia G. Marroni, Elayne Vieira Dias, Felipe Hertzing Farias, Cláudia Herrera Tambeli.}

\section{Resumo}

A dor é uma experiência emocional complexa que apresenta um componente sensorial-discriminativo e outro afetivoemocional. O componente afetivo envolve a ativação de estruturas límbicas, entre elas o núcleo accumbens (NAc), que participam da via de modulação da dor. Dados prévios do nosso grupo mostraram a participação do fator neurotrófico derivado de cérebro (BDNF) no desenvolvimento da hiperalgesia crônica. A partir disso, o objetivo desse estudo seria analisar o papel do BDNF do NAc no componente afetivo da dor, avaliado pelo paradigma de esquiva condicionada de lugar (CPA). Para tanto, a primeira etapa do presente trabalho consiste na padronização dessa metodologia e posteriormente na manipulação farmacológica do NAc com o antagonista do receptor de BDNF, TrkB.

\section{Palavras-chave:}

Dor; Componente afetivo; Formalina.

\section{Introdução}

A dor pode ser definida como a percepção de uma sensação nociceptiva e inclui as dimensões afetivomotivacional e cognitivo-avaliativa, além da dimensão sensorial-discriminativa. O componente afetivo-emocional depende de fatores como aprendizagem, memória e recompensa (CALVINO e GRILO, 2006) e pode ser avaliado em animais através do paradigma da esquiva condicionada de lugar (CPA - Conditioned Place Avoidance; JOHANSEN et al., 2001).

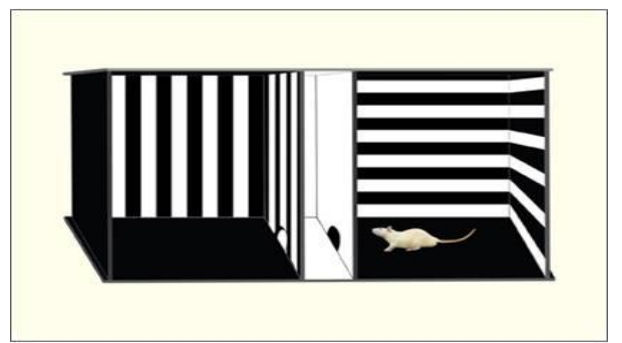

Figura 1. Desenho esquemático do aparato para avaliação do componente afetivo da dor (CPA).

O objetivo deste estudo é avaliar a participação do BDNF do NAc no componente afetivo da dor. A primeira etapa foi, portanto, a padronização do CPA onde diferentes protocolos foram utilizados.

\section{Resultados e Discussão}

\section{- Capsaicina - Protocolos 1, 2 e 3}

Como apresentado na figura 2 , não houve alteração significativa no comportamento dos animais quando as sessões de pré-condicionamento foram comparadas à sessão de teste, pós-condicionamento. Portanto, a capsaicina injetada na pata não induziu esquiva condicionada de lugar.

\section{- Formalina - Protocolos 1 e 2}

Nos protocolos testados (Figura 3), o tempo gasto pelos animais em cada compartimento na sessão de précondicionamento não foi significativamente diferente do tempo gasto em cada compartimento após o condicionamento, na sessão de teste. Assim, nos protocolos utilizados a formalina injetada na pata não induziu esquiva condicionada de lugar.
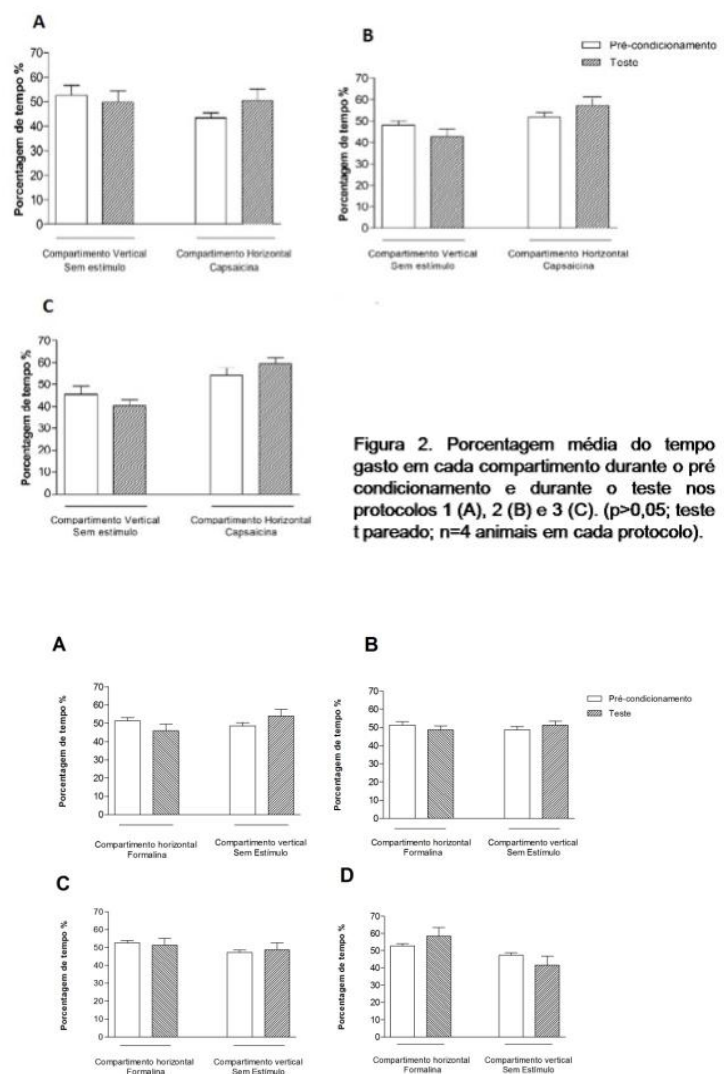

D

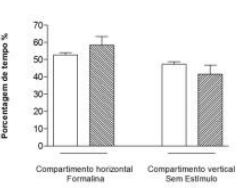

Figura 3. Porcentagem média do tempo gasto em cada compartimento durante o pré-condicionamento e durante o teste nos protocolos 1 ( $A$ e $B$ ) e 2 (C e D). ( $p>0,05$; teste t pareado; $n=12$ animais em cada protocolo).

\section{Conclusões}

Não foi possível replicar, com base nos protocolos disponíveis na literatura, o Teste de Esquiva condicionada de Lugar (CPA).

\section{Agradecimentos}

Ao CNPq pelo suporte financeiro.

\section{Referências:}

CALVINO B; GRILO RM. (2006) Central pain control. Joint Bone Spine. 73,10-16.

JOHANSEN, J. P.; FIELDS, H. L.; MANNING, B. H. (2001) The affective component of pain in rodents: Direct evidence for a contribution of the anterior cingulate cortex. Proc Natl Acad Sci, v. 98(14), p.8077-8082.

XXIV Congresso de Iniciação Científica da UNICAMP 